\title{
Stakeholder's Perspective on Green Building Rating Systems in Saudi Arabia: The Case of LEED, Mostadam, and the SDGs
}

\author{
Mohammed Al-Surf ${ }^{1, *(\mathbb{D}}$, Ashraf Balabel ${ }^{2}(\mathbb{D})$, Mamdooh Alwetaishi ${ }^{3}\left(\mathbb{D}\right.$, Ahmed Abdelhafiz $^{3}\left(\mathbb{D}\right.$, Usama Issa $^{3}(\mathbb{D}$, \\ Ibrahim Sharaky ${ }^{3}$, Amal Shamseldin ${ }^{3}$ and Mosleh Al-Harthi 4 \\ 1 U.S. Green Building Council and Green Business Certification Institute, Jeddah 23525, Saudi Arabia \\ 2 Mechanical Engineering Department, College of Engineering, Taif University, Taif 21099, Saudi Arabia; \\ a.balabel@tu.edu.sa \\ 3 Civil Engineering Department, College of Engineering, Taif University, Taif 21099, Saudi Arabia; \\ m.alwetaishi@tu.edu.sa (M.A.); a.abdelhafiz@tu.edu.sa (A.A.); u.issa@tu.edu.sa (U.I.); \\ i.sharaky@tu.edu.sa (I.S.); ashamseldin@tu.edu.sa (A.S.) \\ 4 Electrical Engineering Department, College of Engineering, Taif University, Taif 21099, Saudi Arabia; \\ m.harthi@tu.edu.sa \\ * Correspondence: malsurf@gbci.org
}

check for updates

Citation: Al-Surf, M.; Balabel, A.; Alwetaishi, M.; Abdelhafiz, A.; Issa, U.; Sharaky, I.; Shamseldin, A.; Al-Harthi, M. Stakeholder's Perspective on Green Building Rating Systems in Saudi Arabia: The Case of LEED, Mostadam, and the SDGs. Sustainability 2021, 13, 8463. https:// doi.org/10.3390/su13158463

Academic Editors: Georgia Warren-Myers and András Reith

Received: 31 March 2021

Accepted: 25 June 2021

Published: 29 July 2021

Publisher's Note: MDPI stays neutral with regard to jurisdictional claims in published maps and institutional affiliations.

Copyright: (c) 2021 by the authors. Licensee MDPI, Basel, Switzerland. This article is an open access article distributed under the terms and conditions of the Creative Commons Attribution (CC BY) license (https:// creativecommons.org/licenses/by/ $4.0 /)$.

\begin{abstract}
This paper discusses in detail the current level of awareness of the Saudi Arabia stakeholders regarding the use and application of green building rating systems. The paper used a mix of qualitative and quantitative research methods through an exploratory method that utilized an online survey targeting experts and construction stakeholders to fill the gap of previous research papers and support the argument of the increase in the level of the awareness of stakeholders in the use and application of green building rating systems in Saudi Arabia. This research aims to focus on the level of awareness of the Saudi construction market stakeholders on green building rating systems in Saudi Arabia with focus on the Leadership in Energy and Environmental Design system LEED and Mostadam. It also investigated which rating system responds to the need of the Saudi construction market with regard to energy conservation and water consumption more effectively. The methodology utilized in this research used a combination of primary and secondary data where the primary data were a survey sent to Saudi construction stakeholders where a total of 1320 respondents participated in the survey. Results from this research showed a promising number of agreements between the participating stakeholders to the level of awareness of green building rating systems in Saudi Arabia and to the willingness to use internationally recognized rating systems such as LEED and the use of locally recognized systems such as Mostadam. Furthermore, the research aims to link the results with the Sustainable Development Goals (SDGs) with a focus on SDGs 6 and 7. The results show a high level of appreciation and agreement to the importance of energy and water conservation in green buildings that will be using either LEED or Mostadam in Saudi Arabia and accomplish the targets outlined under the SDGs.
\end{abstract}

Keywords: green building; sustainable buildings; sustainable development; stakeholder awareness; Mostadam; LEED; sustainable development goals

\section{Introduction}

Saudi Arabia is one of the countries that has developed rapidly in the last four decades. In the seventies, oil prices increased, which had a very positive impact on the Saudi economy, which led to an increasing rate in the construction industry. Urbanization since that time has begun to increase at a noticeable rate. Due to increasing business opportunities found in the country in general and some cities specifically such as Riyadh, some people have found it to be a great city for business development and started moving there, which has led to an increase in its population. The population has increased frequently, which has increased the demand in buildings that have direct positive and negative impacts on 
the construction industry. Hence, the construction industry, due to the high demand, has started rapidly developing [1,2]. Manufacturing plants for the main construction materials (e.g., cement, ready mixed concrete, steel and other materials) were built to accommodate for this rapid urban expansion. Since that time, the population increase has had a direct impact on the construction industry and indirect impacts in other fields that support urban life $[3,4]$.

Meanwhile, increasing the urban area has shown a negative impact on the environment by increasing air pollution, house emissions, high demand on water resources, high energy consumption, and solid waste challenges. In this regard, Al Surf [5] stated "Rapid urbanization in developing countries is putting stress on current infrastructure, which is resulting in the rapid consumption of natural resources to cope with the increasing demand of the population". The Saudi level of urbanization has increased from 21 per cent in 1950 to 83 per cent in 2015 [6].

At the current urbanization rate, greenhouse gas (GHG) emissions will keep rising and the effects of climate change will keep affecting our daily lives negatively. Saudi Arabia's heavy reliance on fossil fuels for energy generation and transportation is the biggest contributor to GHG emissions in the country. It is staggering to find that urban areas only cover about $3 \%$ of the Earth's surface, yet they consume about $80 \%$ of global energy and account for around $70 \%$ of global $\mathrm{CO}_{2}$ emissions [7]. These emissions can be mitigated by shifting the way we construct our buildings from traditional energy consuming methods to a more sustainable way. This can be done through the help of sustainable and green building rating systems.

To reduce the environmental impacts of buildings such as $\mathrm{CO}_{2}$ emissions and water and energy consumption, the Saudi Arabian government promotes the construction of green buildings that use less energy and water consumption, provide better indoor air quality, economically saves in the short- and long-term with fast paybacks, and can promote better social livelihoods for the population [7]. Saudi Arabia is investing USD\$1.154 billion worth of green building projects. In Riyadh, for example, the King Abdullah Financial District (KAFD) — a 160 ha green building development that is a LEED ND certified projecthas been completed [8]. There is also a plan to retrofit 90,000 mosques to make them more energy-efficient, with the target to lower their electricity consumption by about $40 \%$ and water use by $30-40 \%$ [9].

The implications of the findings for the use of green building rating systems in Saudi Arabia to help in mitigating the country's climate change effects will be discussed from a stakeholder's perspective. In addition, being the largest economy in the Gulf region, Saudi Arabia is an interesting case study as it faces high energy intensity, large amounts of construction and demolition waste as well as huge amounts of water consumption. Our study aims to contribute to the understanding on the use of green building rating systems in Saudi Arabia, specifically LEED and Mostadam, and evaluate the construction industry stakeholders' perspectives on their level of awareness and the willingness to use the two rating systems in residential projects in the country. We will also gain insights for future green building trends and contribute to the development of more stringent construction practices that will help mitigate climate change.

\section{Literature Review and Hypothesis}

This research aims to focus on the following questions:

1. What is the level of awareness of the construction industry stakeholders on green building rating systems in Saudi Arabia?

2. Which rating system would stakeholders prefer to use between LEED and Mostadam in Saudi Arabia?

3. Which rating system, from the stakeholders' perspective, responds to the need of the Saudi construction market with regard to energy conservation and water consumption in residential projects more effectively and can accomplish the targets of SDG6 and SDG7? 
It will be discussed through this research how those that are spreading the message about green building such as industry experts is vital to the widespread acceptance and use of green building rating systems. Hence, by exposing how green building experts talk about the issue or agree on the topic, we may begin to understand how public support for green buildings can reach the kind of mainstream acceptance as other planning and design techniques such as New Urbanism have.

\subsection{Sustainable Development Goals (SDGs) and Green Buildings}

Sustainability has been defined in numerous ways and aspects that are overwhelming, but we can generally relate to the Report of the World Commission on Environment and Development: Our Common Future, which states "Sustainable development is development that meets the needs of the present without compromising the ability of future generations to meet their own needs." [10]. Although somewhat vague, this concept of sustainable development aims to maintain economic advancement and progress while protecting the long-term value of the environment as it "provides a framework for the integration of environment policies and development strategies" [10]. The overall goal of sustainable development (SD) is the long-term stability of the economy and environment; this is only achievable through the integration and acknowledgement of economic, environmental, and social concerns throughout the decision-making process [11,12].

The need for sustainable development is truly recognized by all countries and thus in 2015, the UN developed the Millennium Development Goals (MDGs) further and introduced the 17 Sustainable Development Goals (SDGs) to be achieved by 2030. In September 2015, United Nations' Member States jointly decided on a global project to shape our common future in a new, better, and more intentional way. Building upon wide consultations with civil society representatives, business people, scientists, and others, they established the 2030 Agenda for Sustainable Development. Entitled Transforming Our World, this project reflects the global community's high expectations of finally reversing the destruction of our natural and social habitats and achieving a more balanced and equitable pathway toward the well-being of all $[13,14]$.

Green buildings (GBs) are aligned with the UN's SDGs and this is detailed in this section to show the link between SDGs and GBs. "The 2030 Agenda for SD is a plan of action for the people and the planet, which focuses on environmental issues and resource depletion through human activities [15]. As the triple bottom line of sustainability is the cornerstone of green buildings, it is imperative that the link is established here between GBs and SDGs. However, the SDGs are not just responding to the 3Ps, but provide more detail on the 5Ps, which are people, planet, prosperity, peace, and partnership. It is also important to clearly state that the sole purpose and function of the SDGs is to "maintain stability among the economic, social, and environmental aspects, which would promote universal changes towards a sustainable future" [15]. Table 1 illustrates the SDGs and their definitions; for the purpose of this paper, the focus will be on linking Goals 6, 7, 11, and 13 to GBs.

Table 1. The 17 SDGs [16].

\begin{tabular}{ccc}
\hline SDGs & Goals & Definition \\
\hline $\mathrm{SDG}_{1}$ & No Poverty & $\begin{array}{r}\text { Economic growth must be inclusive to provide sustainable jobs and } \\
\text { promote equality. }\end{array}$ \\
$\mathrm{SDG}_{2}$ & Zero Hunger & $\begin{array}{r}\text { The food and agriculture sector offers key solutions for development, } \\
\text { and is central for hunger and poverty eradication. }\end{array}$ \\
$\mathrm{SDG}_{3}$ & Good Health \& Well Being & $\begin{array}{c}\text { Ensuring healthy lives and promoting the well-being for all at all ages } \\
\text { is essential to sustainable development. }\end{array}$ \\
$\mathrm{SDG}_{4}$ & Quality Education & $\begin{array}{r}\text { Obtaining a quality education is the foundation to improving people's } \\
\text { lives and sustainable development. }\end{array}$ \\
\hline
\end{tabular}


Table 1. Cont.

\begin{tabular}{|c|c|c|}
\hline SDGs & Goals & Definition \\
\hline $\mathrm{SDG}_{5}$ & Gender Equality & $\begin{array}{l}\text { Gender equality is not only a fundamental human right, but a } \\
\text { necessary foundation for a peaceful, prosperous and sustainable world. }\end{array}$ \\
\hline $\mathrm{SDG}_{6}$ & Clean Water \& Sanitation & $\begin{array}{l}\text { Clean, accessible water for all is an essential part of the world we want } \\
\text { to live in. }\end{array}$ \\
\hline $\mathrm{SDG}_{7}$ & Affordable \& Clean Energy & Energy is central to nearly every major challenge and opportunity. \\
\hline $\mathrm{SDG}_{8}$ & Decent work \& Economic Growth & $\begin{array}{l}\text { Sustainable economic growth will require societies to create the } \\
\text { conditions that allow people to have quality jobs. }\end{array}$ \\
\hline $\mathrm{SDG}_{9}$ & Industry, Innovation \& Infrastructure & $\begin{array}{l}\text { Investments in infrastructure are crucial to achieving } \\
\text { sustainable development. }\end{array}$ \\
\hline $\mathrm{SDG}_{10}$ & Reduced Inequalities & $\begin{array}{l}\text { To reduce inequalities, policies should be universal in principle, paying } \\
\text { attention to the needs of disadvantaged and marginalized populations. }\end{array}$ \\
\hline $\mathrm{SDG}_{11}$ & Sustainable Cities \& Communities & $\begin{array}{l}\text { There needs to be a future in which cities provide opportunities for all, } \\
\text { with access to basic services, energy, housing, transportation and more. }\end{array}$ \\
\hline $\mathrm{SDG}_{12}$ & $\begin{array}{l}\text { Responsible Production \& } \\
\text { Consumption }\end{array}$ & Responsible Production and Consumption \\
\hline $\mathrm{SDG}_{13}$ & Climate Action & Climate change is a global challenge that affects everyone, everywhere. \\
\hline $\mathrm{SDG}_{14}$ & Life Below Water & $\begin{array}{c}\text { Careful management of this essential global resource is a key feature of } \\
\text { a sustainable future. }\end{array}$ \\
\hline $\mathrm{SDG}_{15}$ & Life on Land & $\begin{array}{c}\text { Sustainably manage forests, combat desertification, halt and reverse } \\
\text { land degradation, halt biodiversity loss }\end{array}$ \\
\hline $\mathrm{SDG}_{16}$ & Peace, Justice \& Strong Institutions & $\begin{array}{l}\text { Access to justice for all, and building effective, accountable institutions } \\
\text { at all levels. }\end{array}$ \\
\hline $\mathrm{SDG}_{17}$ & Partnerships for the Goals & Revitalize the global partnership for sustainable development \\
\hline
\end{tabular}

\subsection{Sustainable Development Goals (SDGs) and LEED}

The SDGs help in assessing and formulating various sustainability strategies and initiatives that can dramatically reduce the overall global warming effects of buildings. LEED through the USGBC has developed an advocacy policy to align the SDGs to the LEED credits and categories. Because of the elaborate linkage between the focused SDGs in this paper and between LEED, the discussion here will illustrate how a green building rating system such as LEED can be directly aligned with SDGs 3, 6, 7, 11, and 13.

SDG3 is to ensure healthy lives and promote well-being for all at all ages. Target 3.9 states: By 2030, substantially reduce the number of deaths and illnesses from hazardous chemicals and air, water and soil pollution, and contamination. Healthy populations around the world rely upon sustainable development, and although this goal has focused on health indicators, it should be noted that each of the other 17 SDGs also has significant public health implications. The targets for SDG3 are wide-ranging and address concerns in both developing and developed countries as these global issues affect us all. USGBC sees health as imperative in all of its work. A green building can directly contribute to some of the SDG3 targets. For example, when a project is designed to mimic the natural hydrology and water balance of its site, based on regional undeveloped ecosystems, it can help reduce water contamination and flooding, which can pose health risks downstream, especially when considered cumulatively. Additionally, when projects reduce their fossil fuel us, through energy performance and renewable energy use, they reduce their potential contribution to heat island effects and to local air pollution, both of which have significant health impacts. These building strategies can help protect people in the watershed and airshed, and not only at the project site itself. Green building projects can also support community health by serving functions like providing space for recreation, implementing strategies that address existing health needs and minimizing project features that could present risks to health. LEED pushes project teams and building owners and operators to address the relationship between the indoor environment and human health in a number of ways. The Indoor Environmental Quality credit category in the rating system is dedicated to protecting the health and comfort of building occupants [17]. USGBC, in response to the COVID-19 lockdown, has developed the new USGBC second generation where the theme 
is all about "Healthy People in Places equals a Healthy Economy". Mahesh Ramanujan, the USGBC CEO, stated in January of 2020 "at USGBC, we've always believed that the greatest investment we can make is in each other-in the people we work with and the people we build for. And by investing in GBCI and in new rating systems, we are doubling down on our focus on LEED, on how to promote the issues that most affect our communities like waste, equity and resilience-particularly in the face of climate-related risks—and how to protect the health and well-being of all of us." [18].

SDG6 is to ensure access to water and sanitation for all. Target 6.4 states: By 2030, substantially increase water-use efficiency across all sectors and ensure sustainable withdrawals and supply of freshwater to address water scarcity and substantially reduce the number of people suffering from water scarcity. LEED can help through the water efficiency LEED category, which offers three prerequisites and four credits specifically geared toward reducing water consumption and increasing water efficiency. As an example, the indoor water use reduction prerequisite calls for the installation of water efficient appliances, fittings, and fixtures designed to significantly reduce water use, thus aiding in the effort to combat water scarcity [19].

SDG7 is to ensure access to affordable, reliable, sustainable, and modern energy for all. Target 7.2 states: By 2030, increase substantially the share of renewable energy in the global energy mix. SDG7 Energy consumption has dramatically increased in buildings over the past decade due to population growth; more time spent indoors, increased demand for building functions and indoor environmental quality, and global climate change. Because buildings account for almost $40 \%$ of global energy usage, promoting efficient and sustainable energy use in the building sector is critical to achieving the goals laid out in SDG7. Reducing the carbon footprint and energy usage of buildings is a key part of USGBC's mission and one of the driving forces behind the LEED rating system. High-performing green buildings, like the ones certified under LEED, demonstrate energy efficiency and drive the adoption of sustainable energy technologies [20]. USGBC's flagship program, the LEED rating system, requires projects seeking certification to meet a minimum level of energy performance based on the specific project type. Projects are also required to use building-level energy metering, enabling them to track energy use and identify opportunities for energy savings. Together, these prerequisites ensure a minimum level of energy efficiency in all projects obtaining LEED certification. Projects are encouraged to obtain greater degrees of energy performance by earning voluntary LEED credits. The Energy and Atmosphere credit category is the largest category of voluntary credits under the LEED rating system, making it crucially important in achieving a project's certification goals. Thus, projects are heavily incentivized to increase energy performance past the required minimum, receiving points for achieving certain milestones in energy efficiency [20].

The 11th Sustainable Development Goal (SDG11), "Sustainable Cities and Communities", is to make cities and human settlements inclusive, safe, resilient, and sustainable. Urbanization is happening at a rapid pace in cities around the globe, creating acute environmental, social, and economic challenges in these growing urban areas. SDG11 aims to address these challenges through targets that

- Ensure access to adequate, safe and affordable housing;

- Provide access to green space, reduce air pollution; and

- Prepare for weather-related risks.

In many ways, USGBC's mission echoes the goals and targets of SDG11. USGBC wants to transform the way buildings and communities are designed, built, and operated, enabling a socially responsible, healthy, and prosperous environment that improves quality of life for all. Many credit categories in LEED directly address sustainable cities and communities. For example, LEED's Sustainable Sites category promotes patterns of development that preserve natural systems and help combat urban sprawl. The Location and Transportation category addresses a key element of inclusive cities: access to accessible and affordable transportation. In addition, LEED's new resilient design pilot credit 
rewards projects for addressing risks and vulnerabilities to both natural and human-caused disasters. Going beyond an individual building, the new LEED for Cities and Communities rating system is directly connected to the goals of SDG11. The rating system looks at the economic, environmental, and social health of a city or community and provides a clear means for tracking progress to provide a better quality of life for all residents [21].

Sustainable Development Goal (SDG) 13 calls for governments, nonprofits, private sector actors, and the public to take urgent action to combat climate change and its impacts. The effects of climate change are wide-ranging and will affect lives and economies around the globe. The climate change crisis represents a full-scale tragedy of the commons, as greenhouse gas emissions emitted anywhere in the world contribute to the accumulated atmospheric gases that are trapping heat and warming the planet. USGBC's vision is that buildings and communities will regenerate and sustain the health and vitality of all life within a generation. Addressing climate change is a central tenet of how we undertake our work in support of this vision. Reversing the contribution of buildings to global climate change is a core goal in USGBC's LEED rating system. High-performing green buildings, particularly LEED-certified buildings, can significantly reduce the contribution of greenhouse gas emissions over the life of the building. For this reason, 35 of the 100 total points in LEED v4 are distributed to reward climate change mitigation strategies [22].

\subsection{SDGs in Saudi Arabia}

The Kingdom of Saudi Arabia is committed to implementing sustainable development goals and attaches the highest priority to this endeavor, as commensurate with the Kingdom's specific context and national principles. The Ministry of Economy and Planning (MEP) plays a supporting role to stakeholders and government agencies in strategic planning and implementation. In addition, MEP assigns tasks to government agencies to track and monitor the goals that fall within their jurisdictions. In this regard, the General Authority for Statistics builds the indicators that measure progress made toward the realization of goals through expansion of statistical work carried out to provide the necessary information and data. The Kingdom of Saudi Arabia is experiencing a dramatic and comprehensive transformation through Saudi Vision 2030 and the Vision's twelve implementation programs that are geared to build a robust economy based on a diversified production base and increased competitiveness. The Vision rests on three thematic pillars: a vibrant society, a thriving economy, and an ambitious nation [23].

The Kingdom of Saudi Arabia has made significant investments in water desalination and sanitation, and is witnessing remarkable progress in its ongoing government support. Water and wastewater projects are working rapidly to achieve sustainable environmental development in line with National Transition 2020 and Vision 2030. The Kingdom is also the world leader in desalinated water production with $16.5 \%$ of world production. In retrospect to SDG7, Saudi Arabia has been keen to draw up a vision for an economy less dependent on oil. This is confirmed by the Kingdom's Vision 2030 through diversification of energy sources such as renewable and alternative energy by producing 5.3 gigawatts of renewable energy by 2020 and producing 5.9 gigawatts of renewable energy by 2030 [24].

Data and statistics are critical for each country to take stock of where it stands on the SDGs, to devise pathways for achieving the goals, to identify best practices, and to facilitate peer-learning as well as to track progress over time. According to Sachs et al. [25], Saudi Arabia ranks 98 out of 165 in the 2021 Sustainable Development Report. Figures 1-3 represent how Saudi Arabia is doing against all of the 17 SDGs. The indicators from the 2021 Sustainable Development Report show that Saudi Arabia is moderately improving in SDG6, but is on track and achieving the targets of SDG7. The report shows us that Saudi Arabia still needs much improvement when it comes to achieving SDG6 targets. According to a 2018 reading in the report, anthropogenic wastewater that receives treatment is only at $11.8 \%$. Furthermore, in 2017, the country used freshwater withdrawal at a massive $883.3 \%$ of available freshwater resources [25]. Figures 1-3 illustrate how important it is for Saudi Arabia to speed up the process of achieving the targets of SDG6 and use methods to aid in 
improving the country's performance in SDG6 such as the application of green building methods in future projects. SDG7 performance is much higher when compared to SDG6 in Saudi Arabia. The 2021 Sustainable Development Report shows that population with access to clean fuels and technology for cooking is at $96 \%$. The report also shows that the $\mathrm{CO}_{2}$ emissions from fuel combustion for electricity and heating per total electricity output is $1.4 \mathrm{MtCO}_{2} / \mathrm{TWh}$ [25].

\section{AVERAGE PERFORMANCE BY SDG}

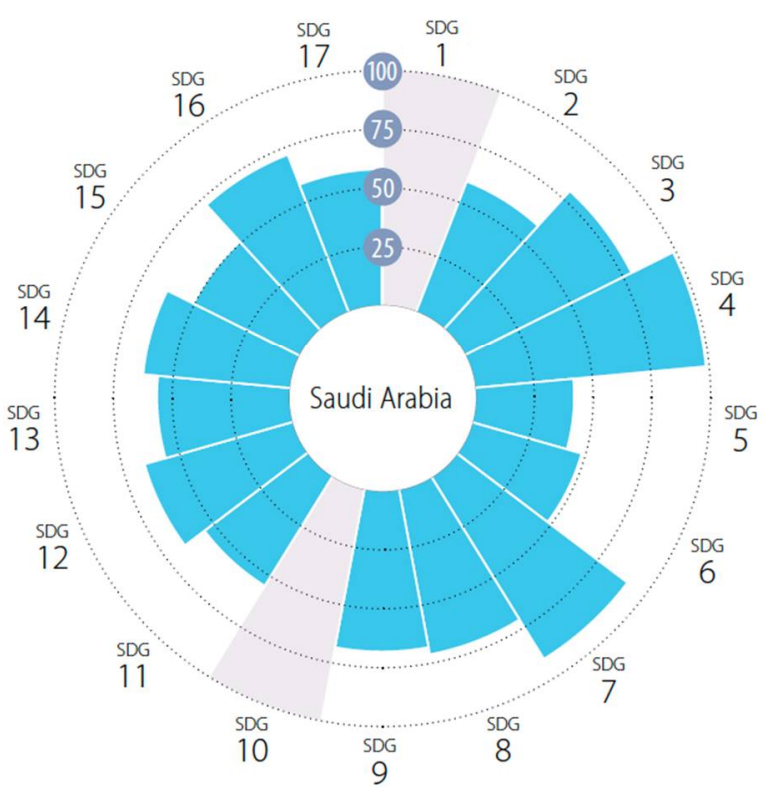

Figure 1. Saudi Arabia average performance by SDG [25].

OVERALL PERFORMANCE

COUNTRY RANKING

COUNTRY SCORE

Saudi Arabia
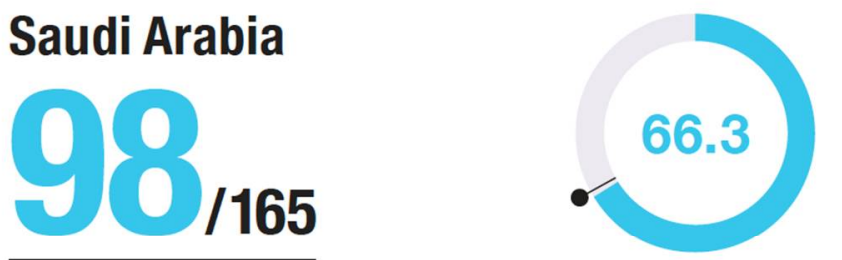

REGIONAL AVERAGE: 67.1

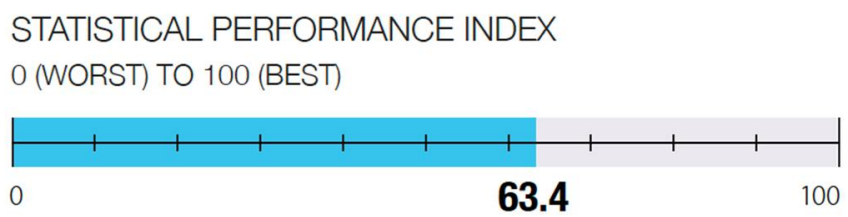

Figure 2. Saudi Arabia overall performance index [25]. 


\section{SDG DASHBOARDS AND TRENDS}
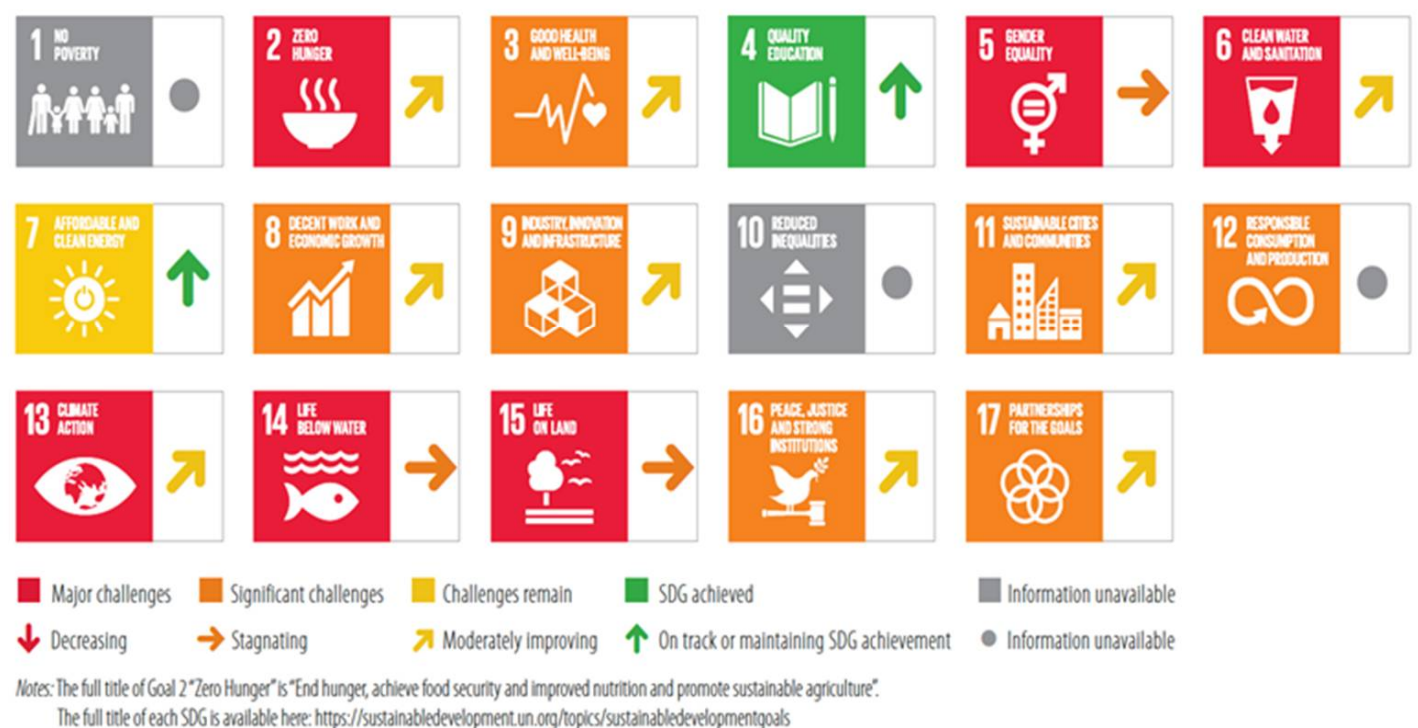

Information unavailable

- Information unavallable The full ittle of each SOG $\mathrm{b}$ arailable here: https://sustanabledevelopmentun.org/topics/sustainablederelopmentgoals

Figure 3. Saudi Arabia SDG dashboard and trends for all SDGs [25].

\subsection{Green Buildings}

A green building can be defined as is a "whole-systems" approach for designing and constructing buildings that conserve energy, water, and material resources and are healthier, safer, and more comfortable [26]. It is common to relate GBs to the economic benefits because they are tangible and we can feel and experience the effects immediately, which is why many sources reason for adopting sustainability in buildings by citing the economic benefits as the key motivators; these include energy savings, environmental gains, health and productivity improvement, or return premiums [27].

In practical terms, a green building includes, but is not limited to, the following aspects:

- Using passive techniques such as solar and wind for natural heating, cooling, and daylighting;

- Landscaping with native plants to conserve water used in irrigation;

- Building quality, durable structures;

- Air-tight designed spaces with good insulation and ventilating appropriately;

- Incorporating salvaged, recycled, and sustainably harvested materials;

- Maintaining healthy indoor air quality with appropriate construction techniques and materials;

- Using energy-efficient and water-saving appliances and fixtures; and

- Reducing and recycling construction waste [28].

Green buildings are designed, constructed and operated to enhance the well-being of occupants, and to minimize negative impacts on the community and natural environment. These types of buildings have been built using the integrative approach, which looks at the building as a whole life cycle approach rather than a linear design and construction approach [29]. The decision to design and build a green building must be considered in the early stages of the building's life cycle to make sure that costs are minimal and all environmental and social aspects are considered. This process involves what is referred to as the "life cycle analysis" and "life cycle costing analysis" [30]. Life cycle analysis in a building (LCA) provides a methodology for evaluating the environmental load of processes and products (goods and services) during their lifecycle from the cradle to the grave. The description of the LCA methodology is based on the International Standards of ISO 14040 [31] and consists of four distinct steps: (i) defining the goal and scope; (ii) creating the lifecycle inventory; (iii) assessing the impact; and (iv) interpreting the results [32]. 
It is well-known that people spend more than 90 percent of their lifetime indoors [33], so it is vital that the indoor environment is well considered and thought of from a wholistic approach, which can only be found in the integrative approach in green buildings. It is common sense to say that a green building is considered a healthy, common sense choice for a better life. As it stands now in traditional construction, the quality of our indoor environment is often far more polluted than the outdoor environment due to various building materials, inadequate lighting, and a variety of other considerations [34,35]. What results from bad indoor environments is a health symptom called "sick building syndrome" (SBS). Sick building syndrome consists of a group of mucosal, skin, and general symptoms that are temporally related to working in particular buildings. It is the workers who are symptomatic, but the building or its services which are the cause" [36,37]. SBS can be caused by many building related factors, which can include:

- Temperature (too high or too low);

- Humidity;

- Poor air ventilation;

- Poor individual control of temperature and lighting;

- Poor building service maintenance; and

- $\quad$ Poor cleaning or cleanability [38].

Green building methodology also requires that fewer natural resources be used during construction. According to the U.S. Department of Energy's Center for Sustainable Development, buildings use 40 percent of the world's total energy, 25 percent of its wood harvest resources, and 16 percent of the world's water supply. Compared to traditional construction, a green built home takes some of this pressure off the environment through deliberate efforts to conserve resources [39].

\subsection{Sustainable Rating Systems Globally}

Over the past decades, global rating systems of buildings of all types have been used as tools to evaluate the levels of sustainability any building is claiming to have. These sustainability rating systems vary from country to country depending on several factors such as energy and water consumption patterns, indoor environment quality parameters, social aspects, and economic factors. The level of detail that any sustainability rating system will follow a set guideline to ensure the authenticity and integrity of that system to make sure it provides the building owner and users with the confidence that the building they are using is sustainable.

It is estimated that there are approximately 600 green rating systems globally [40]. Globally, certain countries have developed their own sustainable rating system that complies with local regulations and international codes. BREEAM (Building Research Establishment Assessment Method) is known as the first rating tool to assess building performance based on certain target values for different criteria. The USA has the Leadership in Energy and Environmental Design (LEED) system, which was developed by the U.S. Green Building Council in 1993. Canada's LEED Canada, France's HQE (High Environmental Quality), Germany's DGNB (Deutsche Gesellschaft für Nachhaltiges Bauen e.V.), Australia's Green Star, New Zealand's Green Star, Japan's CASBEE Building Environmental Efficiency, Hong Kong's BEAM (Building Environmental Assessment Method), Singapore's BCA (Building and Construction Authority), and the list goes on [41].

\subsection{Green Building Rating Systems Used in Saudi Arabia}

A wide range of green building rating and assessment systems are used around the world including LEED and BREEAM, as discussed in the previous section. Sustainability is now a top priority in the MENA region and especially GCC countries like Saudi Arabia, UAE, and Qatar, where they have developed their own green building rating system to incorporate specific socio-economic, environmental, and cultural aspects related to the geo-political characteristics of those countries. 
The UAE, for example, has the ESTIDAMA rating system, while Qatar has the GSAS system. However, for the purpose of this paper, the discussion and analysis focused on LEED and the newly developed Saudi green building rating system Mostadam. In the following two sections, a detailed overview of the two rating systems will be discussed to set forth the necessary background of this paper.

\subsection{LEED}

Leadership in Energy \& Environmental Design (LEED) was established by the U.S. Green Building Council in 1998 with LEED v 1.0 to be the world's leading green building rating system [8]. Since that time, LEED has expanded to address a wide variety of building types and has been periodically updated and revised to reflect new issues and raise performance standards. Twenty-seven years later, LEED is the most widely used green building rating system in the world [42]. LEED predominantly evaluates environmental factors including Sustainable Sites, Water Efficiency, Energy and Atmosphere, Material and Resources, and Indoor Environment Quality categories. All of the building's life cycle could be evaluated based on the criteria from Building Design and Construction, Interior Design and Construction, Building Operations and Maintenance, Neighborhood Development manuals [40]. LEED currently includes the following five main types of building certification, and there are 21 different building adaptations or sub-types illustrated in Table 2:

1. Building Design and Construction (including major renovations) $(B D+C)$

2. Existing Buildings: Operations \& Maintenance $(\mathrm{EB} \mathrm{O}+\mathrm{M})$

3. Interior Design and Construction (ID + C)

4. Neighborhood Development (ND)

5. Homes/Residential (single-family homes, low- and mid-rise residential) (Homes) [8].

Table 2. LEED building adaptations [8].

\begin{tabular}{cc}
\hline LEED Main Rating System & Building Sub-Categories \\
\hline & LEED BD + C: New Construction \\
LEED for Building Design and & LEED BD + C: Core \& Shell \\
Construction & LEED BD + C: Schools \\
(LEED BD + C) & LEED BD + C: Retail \\
& LEED BD + C: Healthcare \\
& LEED BD + C: Data Centers \\
& LEED BD + C: Warehouse and Distribution Centers \\
& LEED BD + C: Hospitality \\
LEED for Existing Building Operation and & LEED O + M: Existing Buildings \\
Maintenance (EB: O + M) & LEED O + M: Data Center \\
& M: Warehouse and Distribution Centers \\
& LEED O + M: Hospitality \\
& LEED O + M: Schools \\
LEED O + M: Retail & LED \\
LEED for Interior Design and Construction & LEED ID + Commercial Interiors \\
(LEED ID + C) & LEED ID + C: Retail \\
& LEED ID + C: Hospitality \\
LEED for Homes & LEED Homes: Low Rise \\
LEED for Neighborhood Design & LEED Homes: Multi-Family Midrise \\
(LEED ND) & LEED ND: Plan \\
& LEED ND: Built Project \\
\hline
\end{tabular}

USGBC has updated the system to LEED v4 and also launched the LEED v4.1 beta version in 2019. LEED v4 categories have remained mostly unchanged from the LEED v3 system, and they are categorized and illustrated in Figure 4. LEED v4.1 is for all-it is more inclusive with updated referenced standards and allows projects to earn LEED points through building performance monitoring. It also continues to drive performance, 
fully integrating performance outcomes supported by new methodologies and a simple data-driven path to measure performance on an ongoing basis [8]. As with any GB rating system, LEED has rating levels, Figure 5, and are calculated based on the credits achieved and ranges from a minimum of 40 to 100 points with 10 bonus points, which takes the total to 110 points. The following figures illustrate the LEED credits and levels of LEED certification levels.

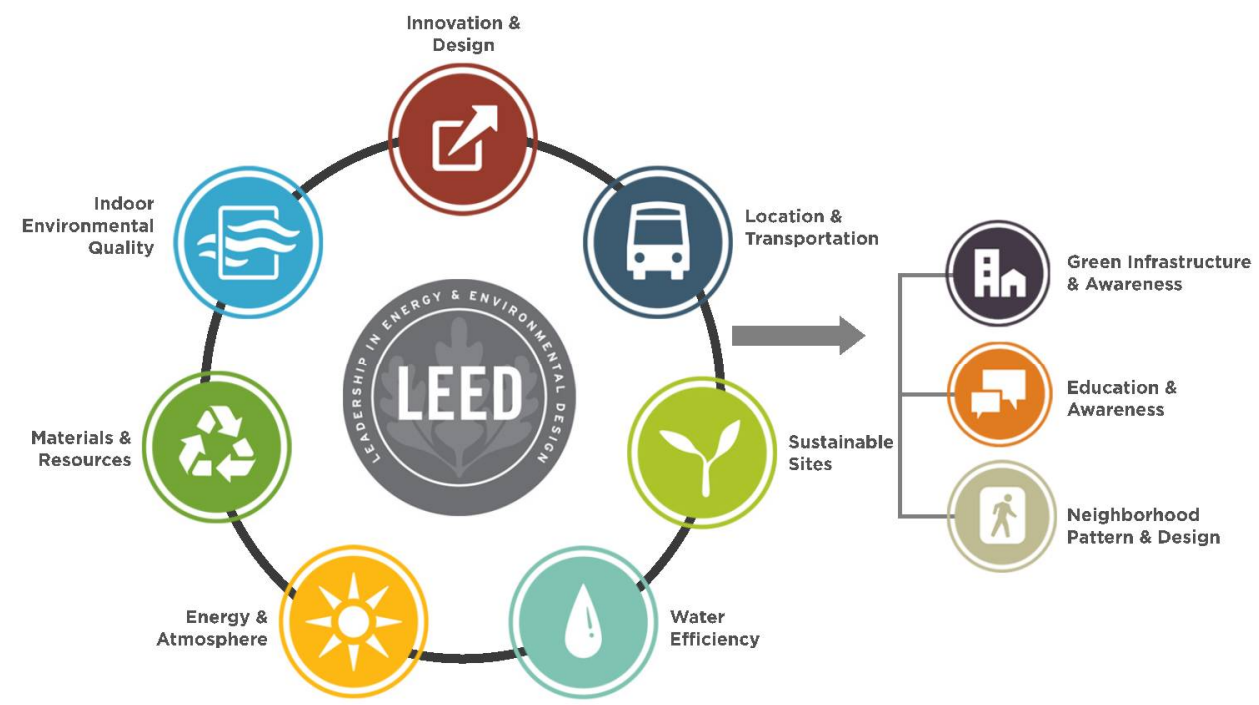

Figure 4. LEED credit categories [43].
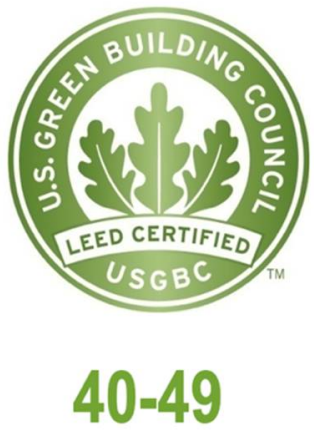
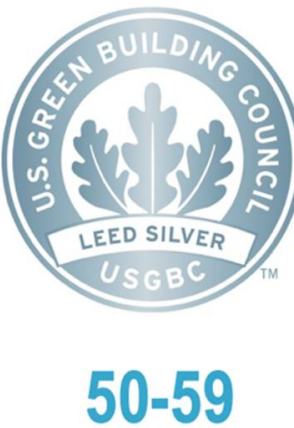
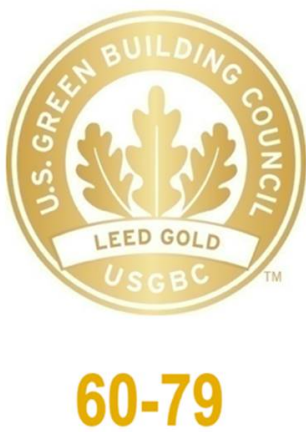

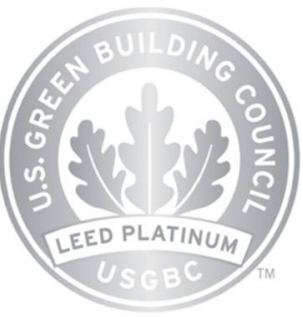

$80+$

Figure 5. LEED certification levels [43].

\subsection{Mostadam}

Mostadam was developed by the Saudi Ministry of Housing under the "Sustainable Building" program as a comprehensive sustainability rating and certification system to address the long-term sustainability of residential buildings in the Kingdom of Saudi Arabia (KSA). Mostadam addresses a wide range of sustainability issues important to the KSA and supports the aspirations of Vision 2030. Like LEED and other rating systems, Mostadam can be used to certify different types of buildings ranging from commercial, residential, and existing buildings. Mostadam is aligned with the Saudi Building Code (SBC), in particular, the Saudi Green Building Code ( $\mathrm{SgBC}$ ), and has been developed to go beyond the minimum $S B C$ requirements to ensure an even higher level of sustainability for residential buildings [5]. The Saudi Building Code (SBC) is a set of legal, administrative, and technical regulations that specify the minimum standards for building design and construction in the KSA. Chapter 10 of the SBC is the Saudi Green Building Code (SgBC 1001) and was developed to ensure that buildings were designed and constructed according to the code and have a lesser impact on the environment [44].

Illustrated in Figure 6 is the alignment between Mostadam and the SBC. The alignment is very important to show here, because the rating's criteria is generated from the three 
most relevant chapters of the SBC. Chapters 501, 601, and 1001 are the core chapters that Mostadam was created from. Mostadam's categories consist of nine main categories:
1. Building Envelope
2. Indoor Air Quality
3. Lighting
4. HVAC
5. Ventilation
6. Renewable Energy
7. Waste
8. Water
9. Comfort

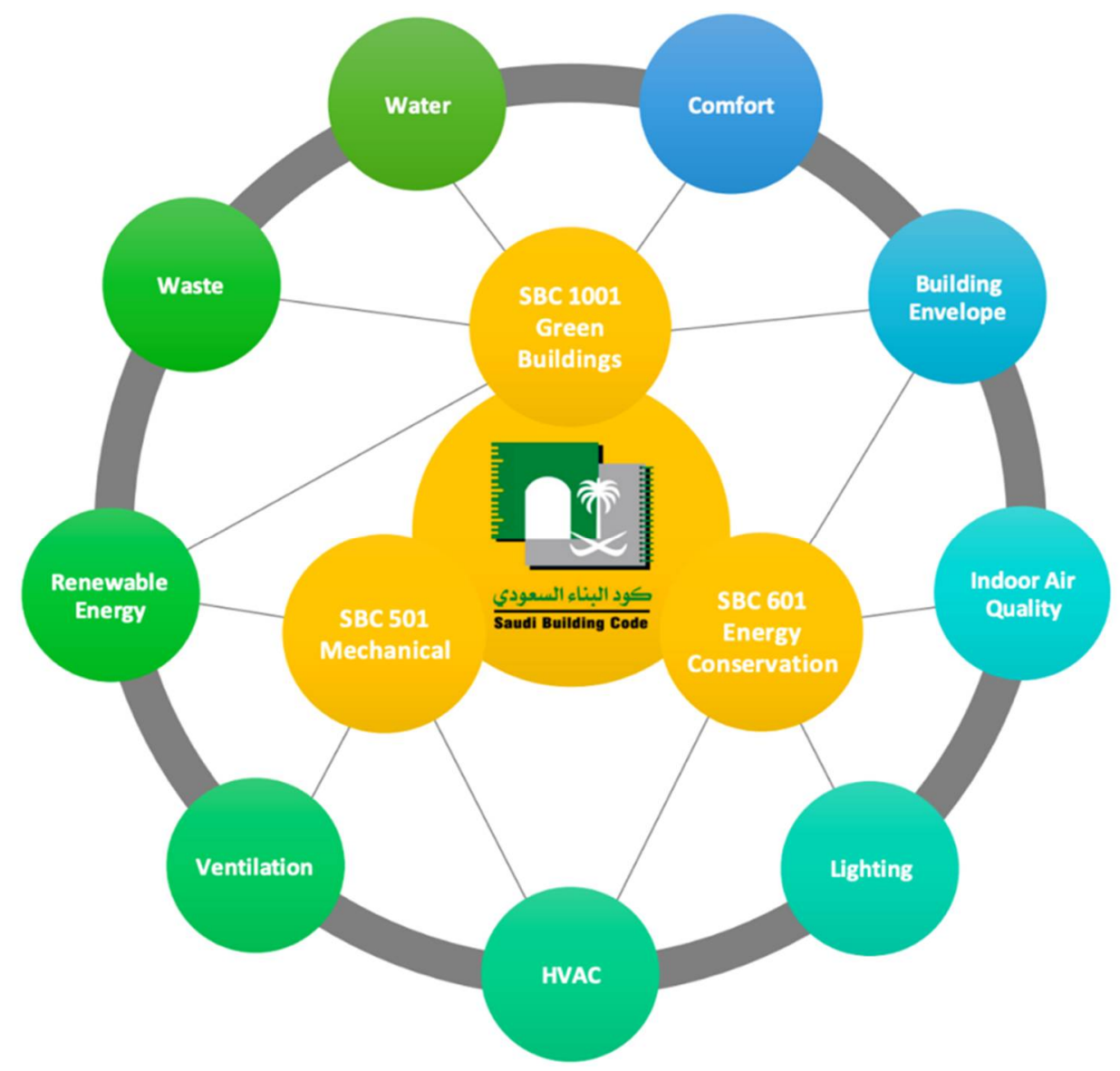

Figure 6. Relationship between SBC and Mostadam for residential buildings [44].

As with any other GB rating system, Mostadam has levels of certification and mainly consists of five levels, as illustrated in Table 3:

Table 3. Mostadam rating levels [44].

\begin{tabular}{cc}
\hline Number of Points & Rating Level \\
\hline $20-34$ & Green \\
$35-49$ & Bronze \\
$50-64$ & Silver \\
$65-79$ & Gold \\
$80-100$ & Diamond \\
\hline
\end{tabular}




\subsection{Stakeholder's Awareness Studies on Sustainable Development}

Research on public support for green building has, to date, been limited in the Arab world, especially in the GCC. Understanding the demographics of individuals that support green buildings has remained secondary to merely determining real opinions on the topic [45].

Embarking on the path of sustainable development will require a profound transformation of how we think and act. To create a more sustainable world and to engage with sustainability-related issues, individuals must become sustainability change-makers. They require the knowledge, skills, values, and attitudes that empower them to contribute to sustainable development. Education, therefore, is crucial in the achievement of sustainable development.

The importance of public awareness to the application of sustainability measures in construction projects in Saudi Arabia is vital to its success and further development. Public perception and awareness has always been a challenge to the wide spread and application of green and sustainable practices in the construction industry. A 2011 study [46] showed in a survey that the public's awareness of sustainable construction practices was very minimal. A more recent study in 2017 [47] found that public awareness in sustainable and green building practices is yet to reach satisfactory levels.

It is therefore the main aim of this paper to analyze the Saudi construction stakeholder's awareness on the development and application of sustainable construction methods through the assessment of their knowledge in green building rating systems in Saudi Arabia using LEED and Mostadam as the main rating tools in the KSA. Following the discovery of how stakeholder knowledge and awareness of the two rating systems used in Saudi is evaluated, a recommendation will be made later in this paper to take the outcomes and evaluate the public's awareness through a wider study.

\section{Methodology}

Researchers constantly use two traditional research approaches (qualitative and quantitative) but they sometimes fall short in the resolution of problems and situations that require new perspectives. In this context, the application of mixed methods approaches is important, which allows us to exploit the strengths of both approaches to achieve a more complete understanding of the problems this paper is embarking on resolving. The paper used qualitative data to help explain the initial quantitative results. The path we took was to use an explanatory research methodology to first collect the quantitative data and analyze them, and then the second phase of qualitative study was developed. Even though explanatory research methodology has some limitations such as the use of a modest number of samples, which could not be for a targeted/ specific type of audience, but it is crucial to obtain a solid background from the surveyed stakeholders to be able to assess their level of awareness and design a framework for future research that will cover a wider range of targeted audience. In short, the mixed methods approach allows for:

1. Combining the strengths provided by the two approaches;

2. Attenuating the weaknesses of their separate application; and

3. Gaining a better understanding of key stakeholders' awareness.

The research method of this paper will be of a mixed method nature, utilizing an on-line survey to collect responses from a wide range of the Saudi society stakeholders in the construction industry. The methodology utilized in this research used a combination of qualitative and quantitative methods where the primary method was a survey sent to the Saudi key stakeholders; a total of 1320 participants took part in the survey. The secondary data support the findings of the primary data by analyzing the relevant literature on sustainability and the stakeholders' awareness to support the argument. 


\section{Research Targeted Audience}

For the purpose of this paper, the targeted audience was Saudi construction market stakeholders. The method of targeting the stakeholders was in collaboration with the Saudi Council of Engineers' database. The Saudi Council of Engineers (SCE) is the Saudi government body that regulates all engineering related professions in the country. With the help of the SCE, the database of the stakeholders was obtained, and an online designed survey was sent to them. The online survey was sent to a total of 23,000 contacts, but only 1320 participated in the survey in the time allocated. Even though the sample size of those who answered the survey was almost $6 \%$ of the total database provided by SCE, this is an exploratory research, which due to several limitations including time and financial constraints, cannot cover the whole SCE database. However, the results will give valuable insights that can be further investigated in future research.

The online survey tool used as the primary data source of this paper is of a qualitative nature and provides the necessary means to evaluate the responses from various industry stakeholders. According to Braun et al. [48], "The survey is a familiar tool in social research. Mixed-method versions incorporate variable amounts of qualitative data collection, but the rich potential qualitative data can offer is often not realized, through data collection and/or analysis". The qualitative survey used for this paper consisted of a series of multiple choice closed-ended questions crafted by the researchers. The survey was self-administered, with questions presented in a fixed and standard order to all participants.

One key advantage of using the survey as the main tool for this research is the "openness and flexibility to address a wide range of research questions of interest to social researchers, as the method allows access to data that range in focus from peoples' views, experiences, or material practices, through to representational or meaning-making practices" [48,49]. Hence, the main tool utilized in this research was the survey sent through an online platform to industry stakeholders covering a wide geographical range from various backgrounds yet has similar interests in sustainable construction applications in the construction sector.

\section{Results and Discussion}

These results build on existing evidence of the stakeholders' awareness of the GB rating system used in Saudi Arabia either from the government's perspective or the private sector. Recent published papers have discussed the stakeholders' awareness to GB application to some extent, such as Alattyih et al., Alkahtani \& Nordin, Alsaati et al. [50-52] where specific stakeholders were targeted such as construction companies. The results discussed herein are a continuation to the efforts of other researchers where we aim to widen and speed up the process of utilizing GB rating systems in Saudi Arabia.

Upon receiving the results from the survey, the first issue to be analyzed was the gender and age range, which are shown in Figure 7, where the majority of male respondents were in the age range of 31-40 years, and the majority of female respondents were in the age range of 20-30 years. Gender gap is quite normal in professions related to the construction market [53] and specially in a country like Saudi Arabia [54]. Prior to the launch of the Saudi Vision 2030, women empowerment was not visible nor publicly announced. However, with the launch of the Saudi Vision 2030, female empowerment is a key pillar in it and much has been done since its launch in 2016. Therefore, the reason for seeing a large gap between male and female respondents is due to the novelty of allowing females to work in the construction market related occupations, and this can be further investigated in future research to see how this gap can be minimized. 


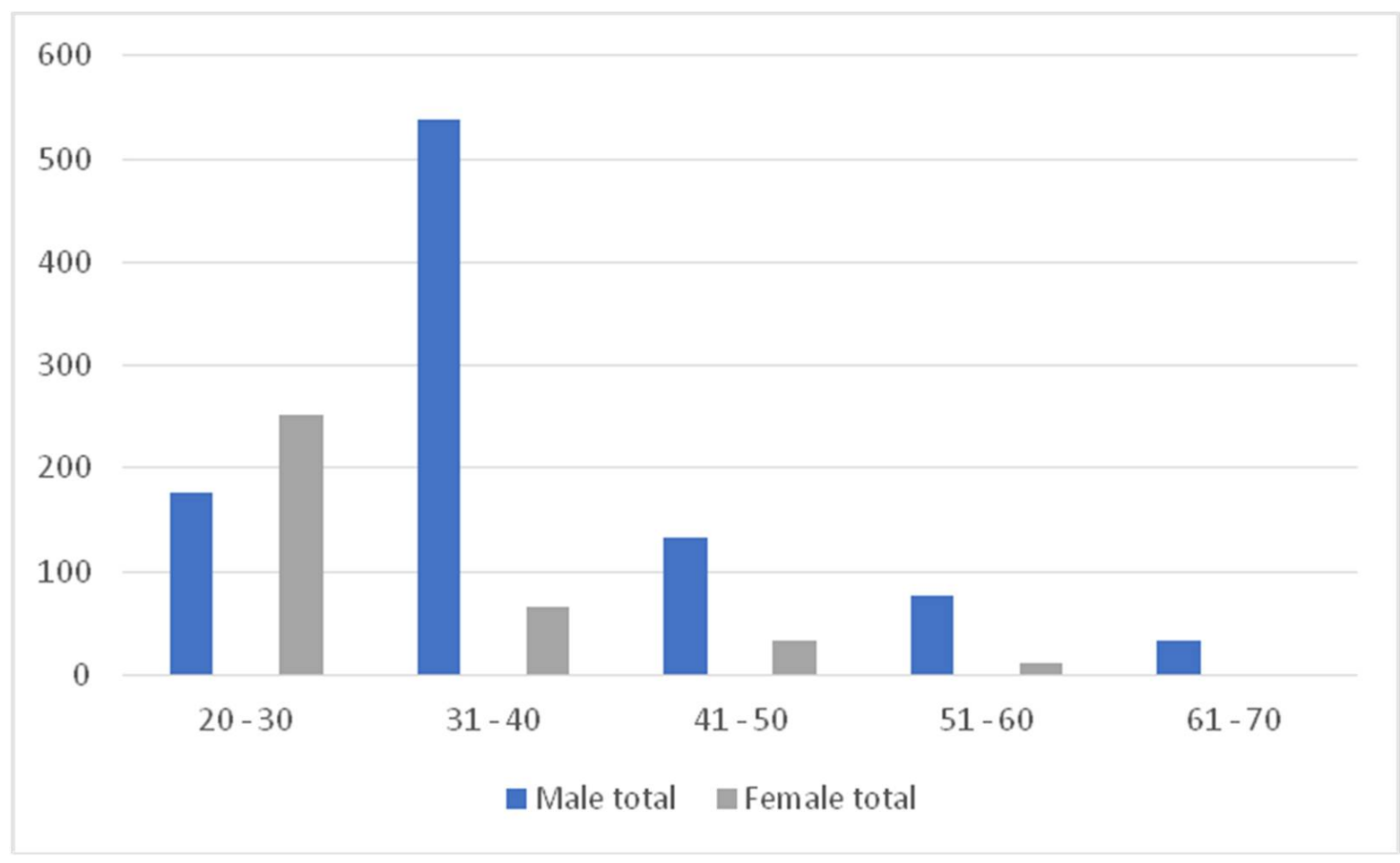

Figure 7. Respondent gender and age range and total responses.

Therefore, when comparing the responses between male and female respondents, we could see that the ratio was 1.4:1 in the age range of 20-30. This age range was the highest range for female participants in the study and this can relate back to the fact that the majority of the Saudi population is in this age group [55]. When we looked at the majority of male respondents, we observed that they fell within the age range of 31-40 years of age. According to the General Authority for Statistics [55], the youth range in Saudi Arabia is between 15 to 34 years of age. Therefore, statistically speaking, the majority of the respondents can be classified as youth if we only count those who have reached the age of 34 in this study. However, this study, through the survey, did not specify a range in between $31-40$ years, so a limitation to this study is to know exactly how many respondents are under the age of 34 .

The second demographical key information needed to authenticate the background of the respondents was job title. Table 4 shows the responses from the respondents who answered the job title question and it is vital to note that some did not answer and left it blank for unknown reasons. We can see from the results that the majority of respondents were architects, project managers, and academics. Further data mining in the work sector that the respondents were from is illustrated in Figure 8, which shows which professions were from the government or private sector. This is important to show and detail because we need to see if the awareness if greater from the public sector side or the private sector side.

For the purpose of this paper and to focus on a specific stakeholder, the analysis here only focused on the respondents who were in the following professions with the highest number of participants: architecture, project management, and academia. Table 5 details the participation tally of the focused stakeholders and in which segment they work. The reason for detailing the responses under these three professions was to understand in which sector we saw the greater awareness and where improvements can be made. The results show that the private sector shows a greater level of stakeholder awareness on the use and application of green building methods in construction. 
Table 4. Respondents' job titles.

\begin{tabular}{cc}
\hline Job Title & Count \\
\hline Architects & 187 \\
Project manager & 176 \\
Academics & 133 \\
Facility engineer/Manager & 99 \\
Sustainability consultant/Engineer/Manager & 88 \\
LEED Architect/Engineer/Director & 66 \\
Civil engineer & 55 \\
Consultant & 44 \\
Director & 44 \\
Interior designer/Architect & 44 \\
Architectural engineer & 33 \\
Mechanical engineer & 33 \\
Electromechanical & 22 \\
Engineer & 22 \\
Architects + Academics & 11 \\
Building energy analyst & 11 \\
Business development manager & 11 \\
Environmental architect & 11 \\
General manager & 11 \\
Urban planner & 11 \\
\hline
\end{tabular}

\section{Employement Sector}

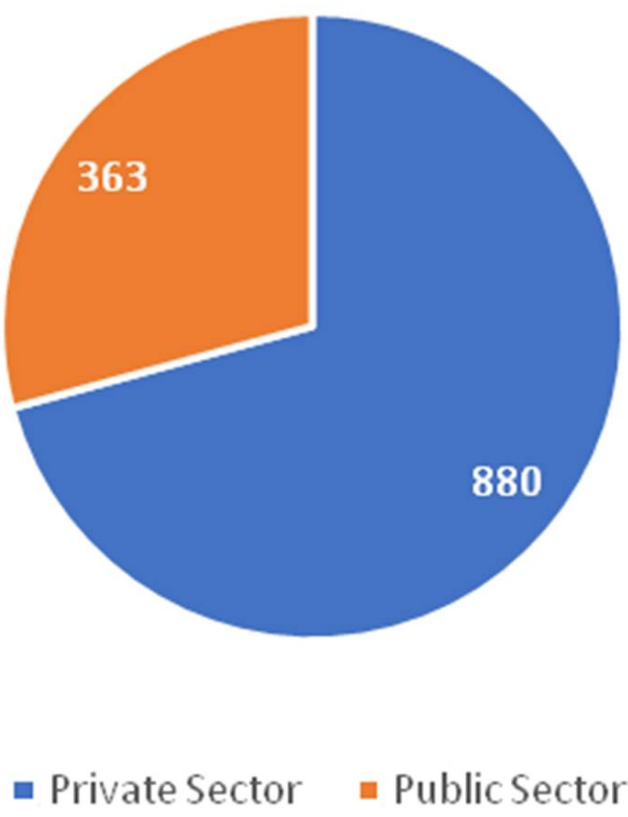

Figure 8. Respondents' employment sector. 
Table 5. Stakeholder segments.

\begin{tabular}{cccc}
\hline & Private & Public & Student \\
\hline Architecture & 88 & 66 & 33 \\
Project Manager & 154 & 22 & 0 \\
Academics & 44 & 88 & 22 \\
\hline
\end{tabular}

To validate the overall level of awareness of the respondents, they were first asked of their knowledge of the basic definition of green buildings. A total of $100 \%$ of the respondents answered "YES" to the question on whether or not they had heard of a green or sustainable building. Furthermore, of the total 1320 participants, 748 respondents had heard of the LEED and Mostadam rating systems, which was about $56 \%$ of the total respondents. The level of awareness in the general public and stakeholders has previously been studied and several publications share the same results, which indicate that even though the level of awareness is still not at the desired level to some, it is still rising and more efforts are needed to increase the level in the general public. Such studies include Mohammed Saied Al Surf et al., Ceasea et al., Gou et al., N. Li, and Ofori-Boadu et al. [56-60].

In the second step, after analyzing the demographics and general awareness of the stakeholders, it is important to analyze the issue of cost as an obstacle to the spread and acceptance of green buildings in any country, but for Saudi Arabia's experts and stakeholders, this research asked the following questions:

"When purchasing your home, would you be willing to pay an additional \$1/sq.m. for a more energy-efficient home or office?"

- $1089(82.5 \%)$ answered Yes, while only

- $44(3.3 \%)$ answered No, and

- $187(14.16 \%)$ were unsure and selected "Maybe" from the answer choices.

- More than $82 \%$ of respondents were willing to pay an extra $\$ 1 /$ sq.m.

For a more energy-efficient home or office, it is clear that the future for a more sustainable and greener built environment can be seen in this generation. There is still around $17 \%$ not sure or not convinced if they can benefit from paying a premium for a home or office that is rated by a green building rating system such as LEED and Mostadam. Several studies have also indicated that if the public is presented with more energy efficient options, they will be willing to pay extra to live or work in a more energy efficient building [61-64].

In the literature review, the issue of indoor environment quality and sick building syndrome (SBS) has been discussed, and it is strongly relevant and causes direct effects to human health. Therefore, the question to the stakeholders regarding indoor environment quality in GB was "Would you pay a premium to improve Indoor Air Quality in your new home or office?"

- $1122(85 \%)$ answered Yes;

- $22(1.6 \%)$ answered No; and

- $\quad 176(13.3 \%)$ were unsure and selected "Maybe" from the answer choices.

With people spending more than $90 \%$ of their life indoors [38,39], this question was very important to emphasize that a clean and healthy indoor environment is vital for our health and well-being. The strong agreement of $85 \%$ of the total respondents who were willing to pay a premium to improve indoor air quality in new homes or offices illustrates how the level of awareness and the importance of living and working a green and sustainable built environment is. However, more than $13 \%$ of respondents were unsure of the question and this will need further investigation and more analysis can be done in future research to the types and gender of those who are unsure and disseminate the results for future researchers. Similar to the results stated above, the following papers have also proven that people would be willing to pay an additional cost to live or/and work in a building with better indoor environment quality [64-67]. 
The results above show that about $85 \%$ of people willing to pay a premium for a better indoor air quality space corresponds to achieving SDG3 (Good Health and Well-Being). Achieving a high number of agreement enforces the need for a better indoor environment for better and healthier lives, even at an extra cost. The results shown here are only for the stakeholders, hence, a further study needs to correlate this level of agreement with the general public. Stakeholders might be willing to pay a premium since their financial status might be higher than average, but further investigation needs to take place for the general public and more specifically, for mid- to low-income families.

Another issue vital to be asked of the stakeholders related to indoor air quality (IAQ) is related to the costs of better building materials that can provide better IAQ:

"Would you consider paying a premium for the use of environmentally sensitive materials that improve Indoor Air Quality in your new home?"

- $1012(76.6 \%)$ answered "Yes";

- $\quad 77(5.83 \%)$ answered "No"; and

- $231(17.5 \%)$ answered "Maybe".

While the level of agreement of the participants to pay a premium for a better indoor air quality was looked at in the previous question, this question answered the synergy between the IAQ of the indoor environment and the building material and how the careful selection of better and sustainable building material could resolve in providing a better IAQ.

Now, going into more detailed aspects such as water conservation and efficiency, the following question was asked of the participants:

"Would you be interested in a water system that uses recycled water for non-drinking water throughout your home?"

- $1001(75.8 \%)$ answered "Yes";

- $\quad 77(5.8 \%)$ answered "No"; and

- $242(18.33 \%)$ answered "Maybe".

The results from the water conservation and efficiency question further enforces the notion of a higher level of awareness and appreciation of the scarcity of water we face in the country and in the region, hence, the awareness of sustainable buildings. With more than $75 \%$ of respondents were willing to switch potable water use with non-potable water in systems that do not need potable water to be used is further evidence of the increased level of awareness and the importance of applying sustainable measures in the built environment. This level of awareness can relate back to SDG6 (Clean Water \& Sanitation) and can help achieve targets 6.4 and 6.5 of SDG6, which are:

- $\quad$ 6.4: By 2030, substantially increase water-use efficiency across all sectors and ensure sustainable withdrawals and supply of freshwater to address water scarcity and substantially reduce the number of people suffering from water scarcity

- 6.5: By 2030, implement integrated water resources management at all levels, including through transboundary cooperation as appropriate [68].

The results from this survey question can reinforce the larger points in the water category under Mostadam when comparing it to LEED. Further analysis in this specific category has been published by Balabel and Alwetaishi [69]. When comparing the level of points awarded in the water category, Mostadam awards higher points than LEED. However, for the energy category, both rating systems award a high number of credits with only a three point difference between them, as illustrated in Figure 9. 


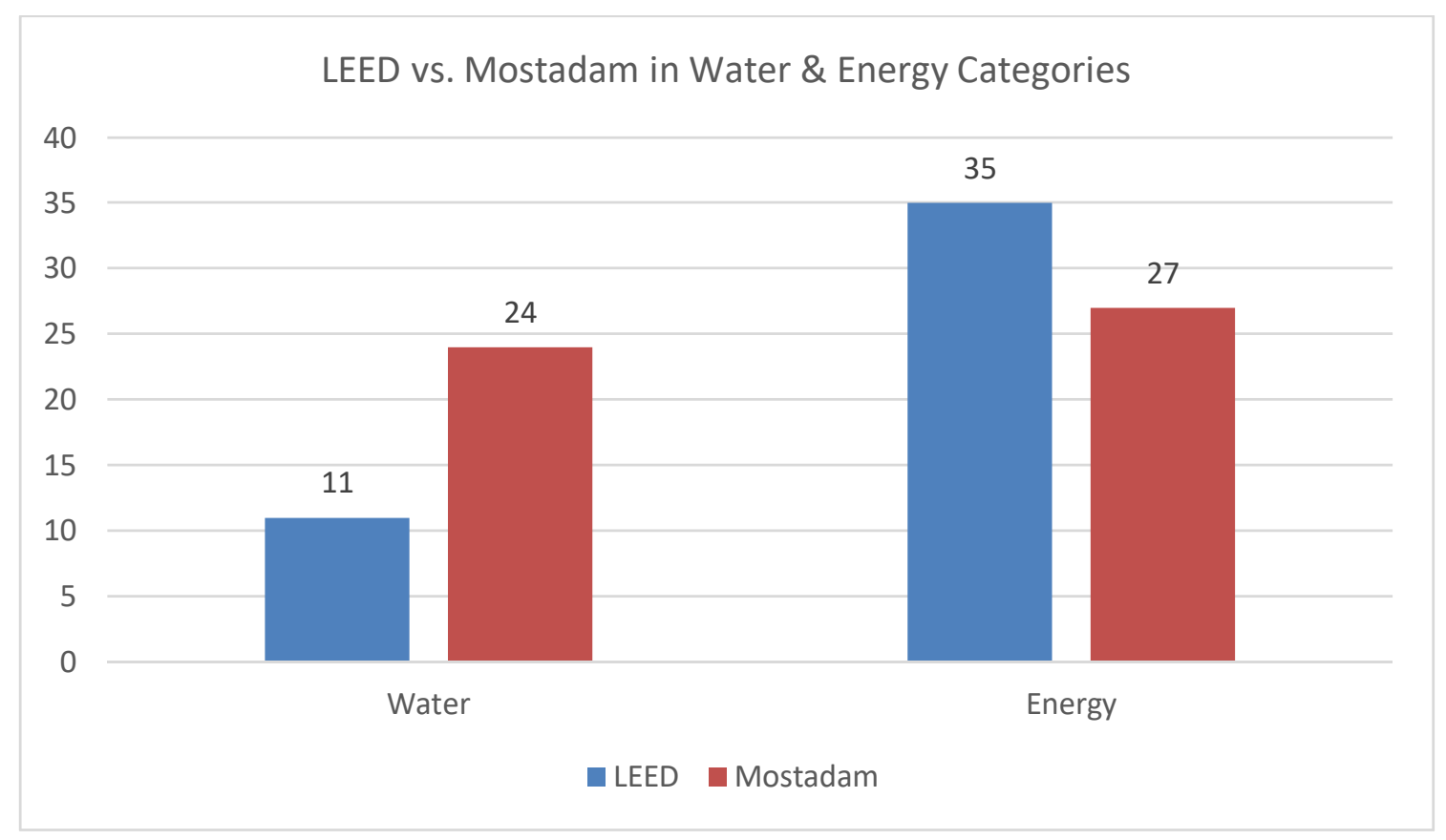

Figure 9. LEED vs. Mostadam in Water \& Energy Categories [70].

Additionally, other studies [70,71] have clearly discussed the water conservation issue in detail and Das et al. [70] defined three main categories of policy instruments in water resource management: authority tools, incentive tools, and capacity building tools. "In authority tools, the governing body implements directives that restrict the quantity of water usage and adoption of water efficient technologies by their consumers. In incentive tools, the consumers are not forced but are given a choice. Such as, consumers saving more water or installing water saving appliances are given rebates on their water consumption bills whereas others are not. In capacity building tool, it is assumed that the consumers do not have adequate knowledge or technology to make the required changes but if given the choice they would opt for the right choice of their own free will. So, capacity building tools take into account the fact that the consumers are willing to make changes in their water usage if provided with adequate information and infrastructures." [70].

Moving from specific building related issues such as cost and IAQ, this section of the discussion is aimed toward the questions raised to the stakeholders on the use of LEED or/and Mostadam as their preferred GB rating system. The participants were asked if they would use an internationally recognized system or a local system green building rating system, and the answers are as follows:

- 759 participants (57.5\%) selected internationally recognized system; and

- 561 participants (42.5\%) selected local green building rating system.

From the answers to this question, it shows that even though an international green building rating system can be available to use, participants would still find it worthwhile using a local green building rating system that might relate to the local sustainability conditions as well as for geo-political reasons, which can be investigated in future research Choosing the right GB rating system is an issue that has been discussed by several authors and papers including Darko et al., Olubunmi et al., and Zhaoa et al. [72-74] and choosing an internationally recognized system is a huge incentive for stakeholders to go for, as indicated by Olubunmi et al. [73].

The local Saudi sustainability and GB rating system "Mostadam" was briefly introduced to the stakeholders in the survey and in the survey, the participants were asked if they would be willing to use it on their buildings. The answers were as follows:

- 814 (61.6\%) answered "Yes"; 
- $\quad 77(5.8 \%)$ answered "No"; and

- $429(32.5 \%)$ answered "Maybe".

The results from this question supports the results from the previous question where more than $61 \%$ of respondents would chose to use Mostadam if it was available to them as a local green building rating system. This result can also support the use of the SBC Green Building Chapter (1001), which was the main foundation on which Mostadam was built.

Moving to more focused building type questions, the participants were asked if they would be willing to use the Mostadam rating system on new or existing buildings, Figure 10. The question states: "Mostadam Rating system is available for new construction as well as for existing buildings. Which building type will you be willing to use this system for?"

- $\quad 418(31.6 \%)$ selected "New Construction";

- $\quad 77(5.8 \%)$ selected "Existing Buildings";

- $759(57.5 \%)$ selected "Both"; and

- $66(5 \%)$ selected "None".

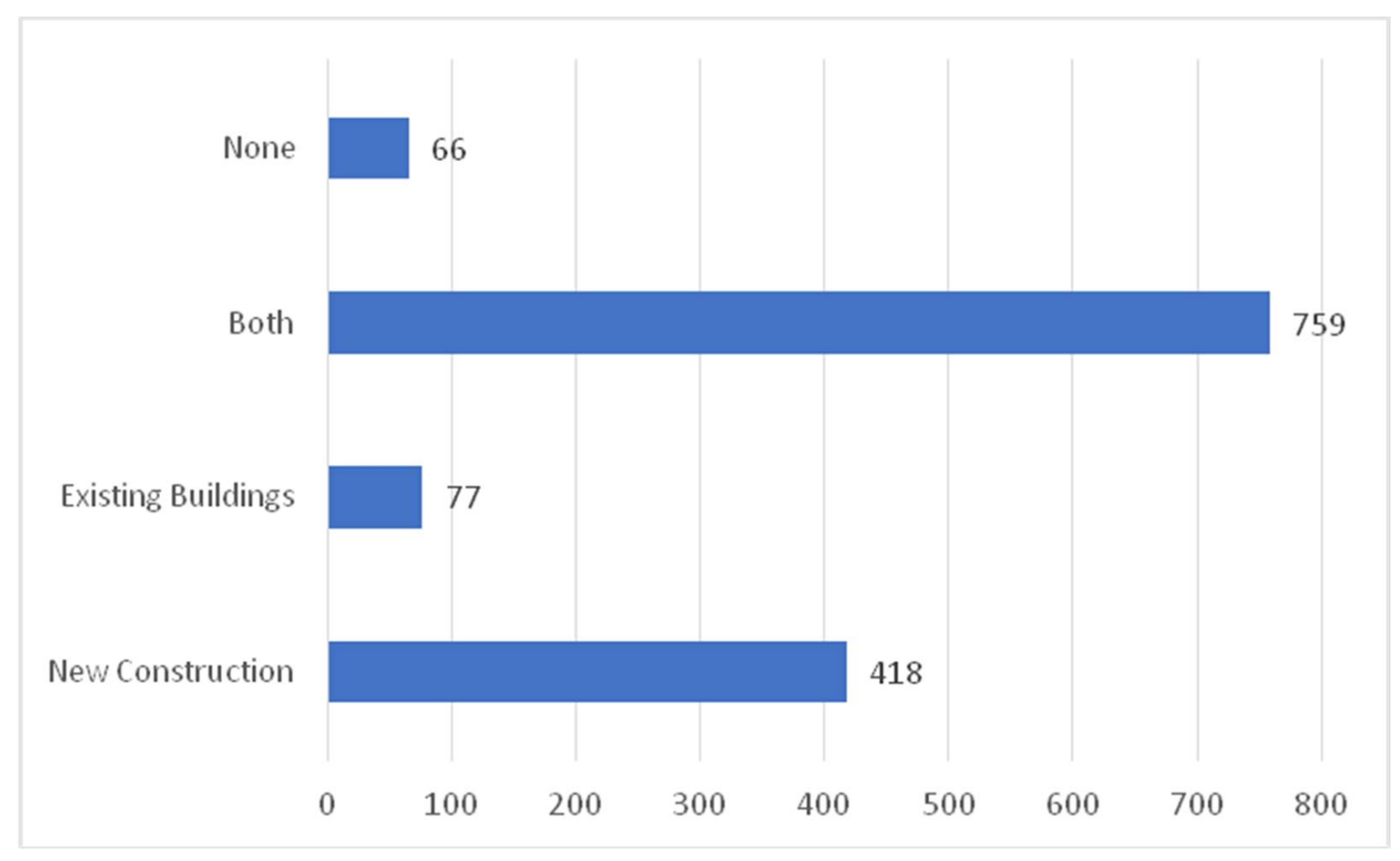

Figure 10. Building type participants willing to use Mostadam system for.

Even though the local green building rating system for the KSA, Mostadam, is available to use, it is still in its infancy compared to LEED and other global rating systems. This hinders the widespread application of Mostadam and can take more time to apply and use in conjunction with LEED in Saudi projects. To validate this statement, the participants were asked the following question:

"There is lack of awareness on the new "Mostadam" rating system because it's new, but there are experts and firms in LEED rating system in Saudi Arabia who have practiced using it in numerous projects. Based on this fact, which system will you feel comfortable using on your building(s)?". The answers are shown in Figure 11. 


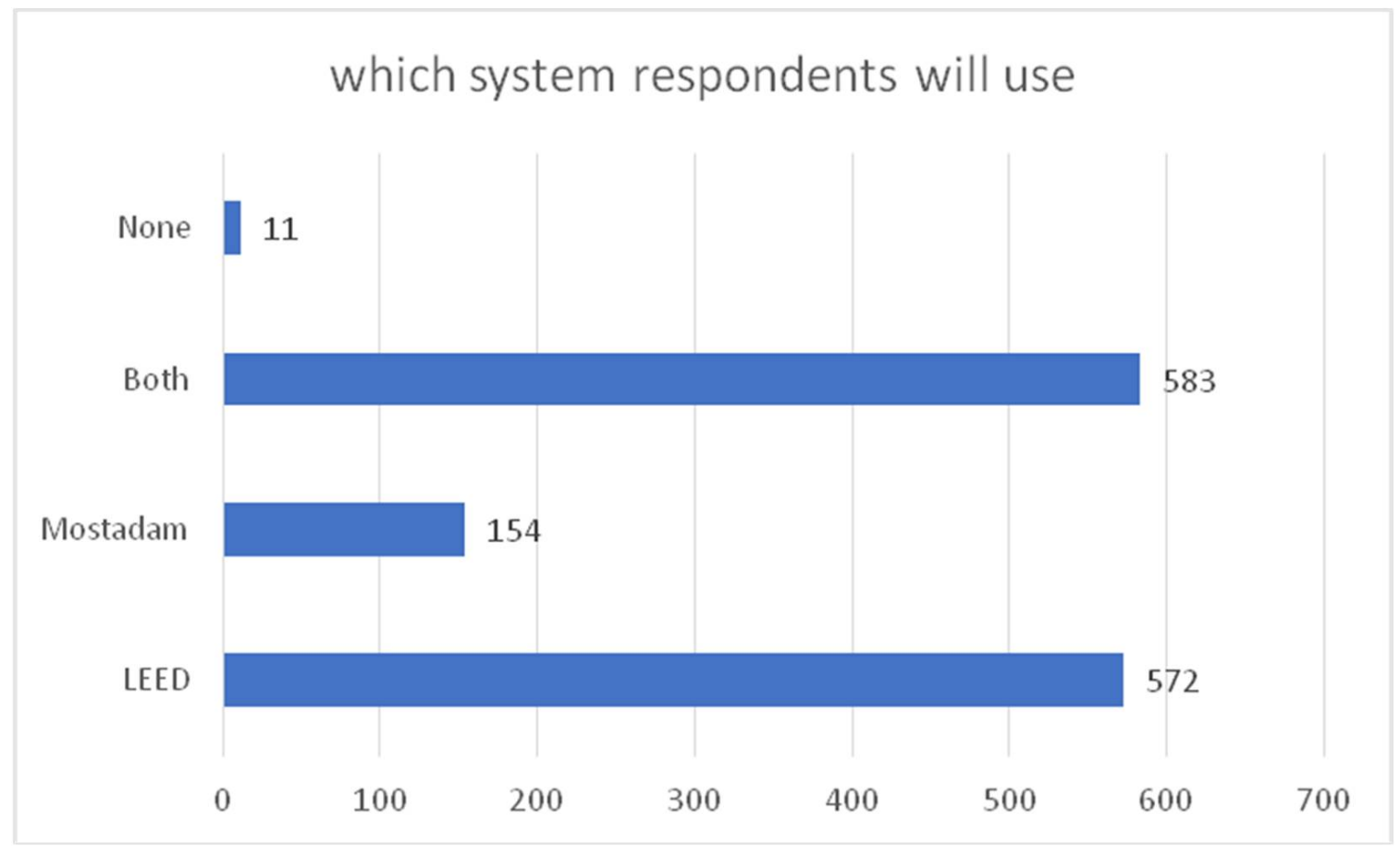

Figure 11. Respondents' choice of preferred rating system.

With respect to the choice between selecting LEED or Mostadam as the preferred green building rating system or both, the respondents clearly showed that LEED superseded Mostadam in the preference of the respondents. Mostadam still showed strength and acceptance to be used in conjunction with LEED. More than $44 \%$ of the respondents selected the preference of using both rating systems, and this will substantiate the result from the question on the level of awareness of the respondents to the concept of green and sustainable buildings.

The final question in the survey was "Do you recommend mandating the use of Mostadam on new and existing buildings?" and the answers were as follows:

- $682(51.6 \%)$ answered "Yes";

- $88(6.6 \%)$ answered "No"; and

- $550(41.6 \%)$ Did not answer this question.

It is evident that more than half of the respondents agreed to mandate the use of the Mostadam green building rating system in new and existing buildings. However, more than $41 \%$ of the respondents did not answer this question, which leaves the question as to why they did not answer it and what this percentage of respondents correlates to the responses of the other questions where they agreed to the use of green building rating systems.

\section{Conclusions and Recommendations}

This paper has discussed in detail the current level of awareness of Saudi Arabian stakeholders with regard to the use and application of green building rating systems. The paper used an online survey targeting experts and construction stakeholders to fill the gap of previous research papers and support the argument of an increase in the level of awareness of the stakeholders to the use and application of green building rating systems.

Responding to the first research question of this paper, the results from the survey showed that the level of awareness between industry stakeholders has increased compared to previous studies and that the current level of awareness of those who were targeted and participated in the survey are at full, $100 \%$, level of awareness and have either used or have been involved in some form with sustainable and green building projects. Furthermore, the 
results from this paper indicate that further investigations need to be done in relation to the gender and age gap between professionals in the construction industry that are involved in sustainable and green building projects.

As for the second research question posed in this paper, the results from the survey indicated that $56 \%$ of the total respondents had heard of LEED and Mostadam. Furthermore, $57.5 \%$ of respondents selected using internationally recognized rating systems, while the remaining 42.5 chose to use locally recognized systems. Additionally, $61.6 \%$ of the total respondents agreed to use Mostadam on their buildings if they were given the choice. As for the type of building, those who were part of the $61.6 \%$, the results showed that $57.5 \%$ were willing to use Mostadam on new and existing buildings. However, the results of the survey showed that even though Mostadam is available, and is considered to better address local climatic, economic, and social conditions, stakeholders were still pitching to use LEED as their preferred rating system. This determination to use LEED as the preferred rating system is normal due to the fact that LEED has evolved over more than 25 years and the market has LEED experts to help buildings secure its certifications and professionals to become accredited. In contrast, Mostadam is still in its infancy and still needs to mature to be able to compete with other rating systems.

Finally, we summarize here the third research question of this paper that is related to which rating system responds to the need of the Saudi construction market in regard to energy conservation and water consumption in residential projects. The survey addressed the energy efficiency through the willingness of the stakeholders to pay an additional $\$ 1$ sq.m. for a more energy-efficient home and the results indicated that more than $82 \%$ agreed to pay the additional costs for a more energy-efficient home. Moreover, $85 \%$ of the stakeholders agreed to pay a premium to have better indoor air quality in their homes. These results enforce the adoption of SDG3 and SDG7, which will help achieve better health and well-being as well as achieve energy conservation targets before 2030 as indicated in the SDG reports. Additionally, we saw that more than $76 \%$ of the respondents were willing to pay more for residential projects that use environmentally sensitive materials that improve indoor air quality, which will eventually reduce the overall energy consumption. As for the water efficiency part of the third research question, the stakeholders showed similar levels of a high percentage of agreement to use recycled water for non-drinking water throughout a house, which will contribute to an overall conservation on the use of potable water in the building. This high level of agreement to use non-potable water will achieve SDG6 and more specifically, the SDG6 targets 6.4 and 6.5, which address the need to conserve potable water consumption, especially in scarce regions such as Saudi Arabia.

To conclude, it is the main recommendation of this paper to further analyze the results of the survey answers and correlate the answers to who agreed and disagreed with the following points:

- $\quad$ Pay an additional $\$ 1$ /sq.m. for a more energy-efficient home or office;

- Pay a premium to improve indoor air quality in a new home or office; and

- Paying a premium for the use of environmentally sensitive materials that improve indoor air quality in new homes.

The extended analysis to these three statements can further enhance the level of application to green building rating systems in Saudi Arabia. While the emphasis on these three points was on the indoor environment and building materials from an economical perspective, it will be worthwhile to advance the study on the social and environmental aspects as well as gender and age specific investigations.

Author Contributions: Conceptualization, M.A.-S.; methodology, M.A.-S.; software, M.A.-S.; validation, M.A.-S., A.B. and M.A.; formal analysis, M.A.-S. and A.B.; investigation, M.A.-S.; resources, M.A.-S., A.B., M.A., A.A., U.I., I.S., A.S., and M.A.-H.; data curation, M.A.; writing-original draft preparation, M.A.; writing—review and editing, M.A. and A.B.; visualization, M.A.-S., A.B., M.A., A.A., U.I., I.S., A.S. and M.A.-H.; supervision, M.A.-S., A.B., M.A., A.A., U.I., I.S., A.S. and M.A.-H.; 
project administration, M.A. and A.B.; funding acquisition, A.B. All authors have read and agreed to the published version of the manuscript.

Funding: This study was funded by the Deanship of Scientific Research, Taif University, Saudi Arabia [Research project number 1-441-108].

Institutional Review Board Statement: Taif University Research Ethics Committee approval number is (42-165) for studies involving humans.

Informed Consent Statement: Informed consent was obtained from all subjects involved in the study.

Data Availability Statement: The data presented in this study are available on request from the corresponding author. The data are not publicly available due to privacy content issues that need further approval from participants.

Conflicts of Interest: The authors declare no conflict of interest.

\section{References}

1. Aboukorin, A.A.; Al-shihri, F.S. Rapid Urbanization and Sustainability in Saudi Arabia: The Case of Dammam Metropolitan Area. JSD 2015, 8, 52. [CrossRef]

2. Alqahtany, A.; Aravindakshan, S. Urbanization in Saudi Arabia and Sustainability Challenges of Cities and Heritage Sites: Heuristical Insights. JCHMSD 2021. Ahead-of-print. [CrossRef]

3. Mahmood, H.; Alkhateeb, T.T.Y.; Furqan, M. Industrialization, Urbanization and CO2 Emissions in Saudi Arabia: Asymmetry Analysis. Energy Rep. 2020, 6, 1553-1560. [CrossRef]

4. Mahmood, H.; Alkhateeb, T.T.Y.; Al-Qahtani, M.M.Z.; Allam, Z.; Ahmad, N.; Furqa, M. Urbanization, Oil Price and Pollution in Saudi Arabia. IJEEP 2020, 10, 477-482. [CrossRef]

5. Al Surf, M.S.; Susilawati, C.; Trigunarsyah, B. The Role of The Saudi Government and The Saudi Building Code in Implementing Sustainable Housing Construction in Saudi Arabia. In Proceedings of the 20th Annual Pacific Rim Real Estate Society Conference. Pacific Rim Real Estate Society, Lincoln, New Zealand, 19-22 January 2014; pp. 1-19.

6. Ministry of Municipal and Rural Affairs. Saudi Cities Report 2019. Available online: https://unhabitat.org/sites/default/files/ 2020/05/saudi_city_report.english.pdf (accessed on 5 June 2021).

7. Abubakar, I.R.; Dano, U.L. Sustainable Urban Planning Strategies for Mitigating Climate Change in Saudi Arabia. Environ. Dev. Sustain. 2020, 22, 5129-5152. [CrossRef]

8. Arab News. Riyadh's King Abdullah Financial District Receives Award for Sustainability Leadership. Arab Nerws. 5 July 2021. Available online: https:/ / www.arabnews.com/node/1888376/saudi-arabia (accessed on 7 June 2021).

9. EL Fouih, Y.; Allouhi, A.; Abdelmajid, J.; Kousksou, T.; Mourad, Y. Post Energy Audit of Two Mosques as a Case Study of Intermittent Occupancy Buildings: Toward more Sustainable Mosques. Sustainability 2020, 12, 10111. [CrossRef]

10. Keeble, B.R. The Brundtland Report: “Our Common Future”. Med. War 1988, 4, 17-25. [CrossRef]

11. Emas, R. Brief for GSDR 2015 The Concept of Sustainable Development: Definition and Defining Principles. 2015. Available online: https:/ / sustainabledevelopment.un.org/content/documents/5839GSDR\%202015_SD_concept_definiton_rev.pdf (accessed on 7 July 2021).

12. Sanchez Rodriguez, R.; Ürge-Vorsatz, D.; Barau, A.S. Sustainable Development Goals and Climate Change Adaptation in Cities. Nat. Clim. Change 2018, 8, 181-183. [CrossRef]

13. Branch, M.P. The Future Is Now. Am. Sci. 2011, 99, 163-164. [CrossRef]

14. Nilsson, M.; Chisholm, E.; Griggs, D.; Howden-Chapman, P.; McCollum, D.; Messerli, P.; Neumann, B.; Stevance, A.-S.; Visbeck, M.; Stafford-Smith, M. Mapping Interactions between the Sustainable Development Goals: Lessons Learned and Ways Forward. Sustain. Sci. 2018, 13, 1489-1503. [CrossRef]

15. Khoshnava, S.M.; Rostami, R.; Zin, R.M.; Štreimikiene, D.; Yousefpour, A.; Strielkowski, W.; Mardani, A. Aligning the Criteria of Green Economy (GE) and Sustainable Development Goals (SDGs) to Implement Sustainable Development. Sustainability 2019, 11, 4615. [CrossRef]

16. Tal, H. The Future Is Now. Alpha Omegan 2019, 102, 155-156. [CrossRef]

17. Olear, G. USGBC's Brief on SDG 3 and How Green Building Can Help Support Its Targets. Available online: https:/ /www.usgbc. org/articles/sustainable-development-goal-3-good-health-and-wellbeing (accessed on 30 May 2021).

18. Ramanujam, M. Next up: Turning the Page to a New Generation of USGBC 2020. Available online: https:/ /www.usgbc.org/ articles/next-turning-page-new-generation-usgbc (accessed on 30 May 2021).

19. UN Water. Summary Progress Update 2021: SDG 6-Water and Sanitation for All. 2021. Available online: https://www.unwater. org/publications/summary-progress-update-2021-sdg-6-water-and-sanitation-for-all/ (accessed on 25 May 2021).

20. Taylor, M. Sustainable Development Goal 7: Affordable and Clean Energy. Advecocy and Policy. Available online: https: //www.usgbc.org/articles/sustainable-development-goal-7-affordable-and-clean-energy (accessed on 7 June 2021).

21. Taylor, M. Sustainable Development Goal 11: Sustainable Cities and Communities. Available online: https://www.usgbc.org/ articles/sustainable-development-goal-11-sustainable-cities-and-communities (accessed on 30 May 2021). 
22. Olear, G. USGBC's Brief on SDG 13 and How Green Building Can Help Support Its Targets. Available online: https://www. usgbc.org/articles/sustainable-development-goal-13-climate-change (accessed on 30 May 2021).

23. Ministry of Economy and Planning. Towards Saudi Arabia's Sustainable Tomorrow, First Voluntary National Review 2018 -1439. 2018. Available online: https://sustainabledevelopment.un.org/content/documents/20230SDGs_English_Report972018_FINAL. pdf (accessed on 7 June 2021).

24. Government of Saudi Arabia Vision 2030 Kingdom of Saudi Arabia. Available online: https://vision2030.gov.sa/download/file/ fid / 417 (accessed on 7 June 2021).

25. Sachs, J.D.; Kroll, C.; Lafortune, G.; Fuller, G.; Woelm, F. Sustainable Development Report 2021. 2021. Available online: https:/ / www.sdgindex.org/reports/sustainable-development-report-2021/ (accessed on 7 July 2021).

26. Kriss, J. What Is Green Building? Available online: https://www.usgbc.org/articles/what-green-building (accessed on 7 June 2021).

27. Goubran, S.; Cucuzzella, C. Integrating the Sustainable Development Goals in Building Projects. J. Sustain. Res. 2019. [CrossRef]

28. Attmann, O. Green Architecture: Advanced Technologies and Materials; McGraw-Hill: New York, NY, USA, 2010.

29. Bruce-Hyrkäs, T.; Pasanen, P.; Castro, R. Overview of Whole Building Life-Cycle Assessment for Green Building Certification and Ecodesign through Industry Surveys and Interviews. Procedia CIRP 2018, 69, 178-183. [CrossRef]

30. Llatasa, C.; Soust-Verdaguera, B.; Passerb, A. Implementing Life Cycle Sustainability Assessment during Design Stages in Building Information Modelling: From Systematic Literature Review to a Methodological Approach. Build. Environ. $2020,182$. [CrossRef]

31. Vigovskaya, A.; Aleksandrova, O.; Bulgakov, B. Life Cycle Assessment (LCA) of a LEED Certified Building. IOP Conf. Ser.: Mater. Sci. Eng. 2018, 365, 022007. [CrossRef]

32. Yeheyis, M.; Hewage, K.; Alam, M.S.; Eskicioglu, C.; Sadiq, R. An Overview of Construction and Demolition Waste Management in Canada: A Lifecycle Analysis Approach to Sustainability. Clean Technol. Environ. Policy 2013, 15, 81-91. [CrossRef]

33. Corlan, R.V.; Balogh, R.M.; Ionel, I.; Kilyeny, S. The Importance of Indoor Air Quality (IAC) Monitoring. J. Phys. Conf. Ser. 2021, 1781, 012062. [CrossRef]

34. Abas, A. Systematic Review On Ecosystem Services For Indoor Systematic Review On Ecosystem Services For Indoor Environment Towards Livable Human. Fresenius Environ. Bull. 2021, 30, 4177.

35. Li, Q.; Mao, X.; Lu, H. In Proceedings of the International Conference on Management and Service Science, Beijing, China, 20-22 September 2009.

36. Burge, P.S. Sick Building Syndrome. Occup. Environ. Med. 2004, 61, 185-190. [CrossRef] [PubMed]

37. Ghaffarianhoseini, A.; AlWaer, H.; Omrany, H.; Ghaffarianhoseini, A.; Alalouch, C.; Clements-Croome, D.; Tookey, J. Sick Building Syndrome: Are We Doing Enough? Archit. Sci. Rev. 2018, 61, 99-121. [CrossRef]

38. Aloudah, S.M. Effects of a Closed Office Environment on the Risk of Sick Building Syndrome in a Medical City in Riyadh, Saudi Arabia: Findings from a Cross-Sectional Study. J. Health Inform. Dev. Ctries. 2020, 14, 1-14.

39. Cao, X.; Dai, X.; Liu, J. Building Energy-Consumption Status Worldwide and the State-of-the-Art Technologies for Zero-Energy Buildings during the Past Decade. Energy Build. 2016, 128, 198-213. [CrossRef]

40. Doan, D.T.; Ghaffarianhoseini, A.; Naismith, N.; Zhang, T.; Ghaffarianhoseini, A.; Tookey, J. A Critical Comparison of Green Building Rating Systems. Build. Environ. 2017, 123, 243-260. [CrossRef]

41. Mattinzioli, T.; Sol-Sánchez, M.; Moreno, B.; Alegre, J.; Martínez, G. Sustainable Building Rating Systems: A Critical Review for Achieving a Common Consensus. Crit. Rev. Environ. Sci. Technol. 2021, 51, 512-534. [CrossRef]

42. Tang, K.H.D.; Foo, C.Y.H.; Tan, I.S. A Review of the Green Building Rating Systems. IOP Conf. Ser. Mater. Sci. Eng. 2020, 943, 012060. [CrossRef]

43. U.S. Green Building Council. Core Concepts Guide, 3rd ed.; U.S. Green Building Council: Wishngton, DC, USA, 2014; ISBN 978-1-932444-34-6.

44. Saudi Arabia Ministry of Housing. Mostadam Rating System for Residential Buildings D + C. Available online: https://www. mostadam.sa/uploads /2019/09/5d91b53e0b866.pdf (accessed on 7 June 2021).

45. Zaidan, E.; Al-Saidi, M.; Hammad, S.H. Sustainable Development in the Arab World-Is the Gulf Cooperation Council (GCC) Region Fit for the Challenge? Dev. Pract. 2019, 29, 670-681. [CrossRef]

46. Susilawati, C.; Al Surf, M. Challenges Facing Sustainable Housing in Saudi Arabia: A Current Study Showing the Level of Public Awareness. In Proceedings of the 17th Pacific Rim Real Estate Society Conference, Gold Coast, Australia, 16-19 January 2011; pp. 1-12.

47. Al Surf, M.S.; Mostafa, L.A. Will the Saudi's 2030 Vision Raise the Public Awareness of Sustainable Practices? Procedia Environ. Sci. 2017, 37, 514-527. [CrossRef]

48. Braun, V.; Clarke, V.; Boulton, E.; Davey, L.; McEvoy, C. The Online Survey as a Qualitative Research Tool. Int. J. Soc. Res. Methodol. 2020, 1-14. [CrossRef]

49. Braun, V.; Clarke, V.; Gray, D. Innovations in Qualitative Methods; Palgrave Macmillan: London, UK, 2017 ; pp. $243-266$.

50. Alattyih, W.; Haider, H.; Boussabaine, H. Risk Factors Impacting the Project Value Created by Green Buildings in Saudi Arabia. Appl. Sci. 2020, 10, 7388. [CrossRef] 
51. Alkahtani, A.; Nordin, N. Conceptual Framework of Green-Building Adoption among Construction Companies in Saudi Arabia: The Effect of Proactive Entrepreneurial Behavior, Green Product Innovation, and Government Support. IJIM 2020, 8, 35-42. [CrossRef]

52. Alsaati, T.; El-Nakla, S.; El-Nakla, D. Level of Sustainability Awareness among University Students in the Eastern Province of Saudi Arabia. Sustainability 2020, 12, 3159. [CrossRef]

53. Froehlich, L.; Olsson, M.I.T.; Dorrough, A.R.; Martiny, S.E. Gender at Work Across Nations: Men and Women Working in Male-Dominated and Female-Dominated Occupations Are Differentially Associated with Agency and Communion. J. Soc. Issues 2020, 76, 484-511. [CrossRef]

54. Alselaimi, R.; Allui, A. Female Employment in Saudi Arabia: Legislative Encouragements and Socio-Cultural Support. In Proceedings of the 8th International Conference on Studies in Education, Law, Economics and Business Management, London, UK, 28 March-14 July 2018.

55. The General Authority for Statistics Saudi Youth in Numbers. Available online: https:/ /www.stats.gov.sa/sites / default/files / saudi_youth_in_numbers_report_2020en.pdf (accessed on 7 June 2021).

56. Al Surf, M.S.; Trigunarsyah, B.; Susilawati, C. Saudi Arabia's Sustainable Housing Limitations: The Experts Views. Smart Sustain. Built Environ. 2013, 2, 251-271. [CrossRef]

57. Ceasea, B.; Kim, H.; Kim, D.; Kob, Y.; Cappelc, C. Barriers and Incentives for Sustainable Urban Development: An Analysis of the Adoption of LEED-ND Projects. J. Environ. Manag. 2019, 244, 304-312. [CrossRef] [PubMed]

58. Gou, Z.; Lau, S.S.-Y.; Prasad, D. Market Readiness and Policy Implications for Green Buildings: Case Study from Hong Kong. J. Green Build. 2013, 8, 162-173. [CrossRef]

59. Li, N. Improving the Understanding of the Green Assessment System/LEED in Developing Countries: The Case of China. Adv. Mater. Res. 2014, 878, 850-865. [CrossRef]

60. Ofori-Boadu, A.; Owusu-Manu, D.G.; Edwards, D.; Holt, G. Exploration of Management Practices for LEED Projects: Lessons from Successful Green Building Contractors. Struct. Surv. 2012, 30, 145-162. [CrossRef]

61. Harajli, H.; Chalak, A. Willingness to Pay for Energy Efficient Appliances: The Case of Lebanese Consumers. Sustainability 2019, 11, 5572. [CrossRef]

62. Ofek, S.; Portnov, B.A. Differential Effect of Knowledge on Stakeholders' Willingness to Pay Green Building Price Premium: Implications for Cleaner Production. J. Clean. Prod. 2020, 251, 119575. [CrossRef]

63. Wiencke, A. Willingness to Pay for Green Buildings: Empirical Evidence from Switzerland. J. Sustain. Real Estate 2013, 5, 111-130. [CrossRef]

64. Yau, Y. Willingness to Pay and Preferences for Green Housing Attributes in Hong Kong. J. Green Build. 2012, 7, 137-152. [CrossRef]

65. Simons, R.; Robinson, S.; Lee, E. Green Office Buildings: A Qualitative Exploration of Green Office Building Attributes. J. Sustain. Real Estate 2014, 6, 211-232. [CrossRef]

66. Stafford, T.M. Indoor Air Quality and Academic Performance. J. Environ. Econ. Manag. 2015, 70, 34-50. [CrossRef]

67. Zalejska-Jonsson, A. Stated WTP and Rational WTP: Willingness to Pay for Green Apartments in Sweden. Sustain. Cities Soc. 2012, 13, 46-56. [CrossRef]

68. United Nations Development Programme Millennium Development Goals and Byond 2015. Available online: https://www.un. org/millenniumgoals / (accessed on 6 June 2021).

69. Balabel, A.; Alwetaishi, M. Towards Sustainable Residential Buildings in Saudi Arabia According to the Conceptual Framework of "Mostadam" Rating System and Vision 2030. Sustainability 2021, 13, 793. [CrossRef]

70. Das, O.; Bera, P.; Moulick, S. Water Conservation Aspects of Green Buildings. Int. J. Res. Eng. Technol. 2015, 04, 75-79. [CrossRef]

71. Rhoads, W.J.; Pruden, A.; Edwards, M.A. Survey of Green Building Water Systems Reveals Elevated Water Age and Water Quality Concerns. Environ. Sci.: Water Res. Technol. 2016, 2, 164-173. [CrossRef]

72. Darko, A.; Chan, A.P.C.; Ameyaw, E.E.; He, B.-J.; Olanipekun, A.O. Examining Issues Influencing Green Building Technologies Adoption: The United States Green Building Experts' Perspectives. Energy Build. 2017, 144. [CrossRef]

73. Olubunmi, O.A.; Xia, P.B.; Skitmore, M. Green Building Incentives: A Review. Renew. Sustain. Energy Rev. 2016, 59, 320-332. [CrossRef]

74. Zhaoa, D.-X.; He, B.-J.; Johnson, C.; Mou, B. Social Problems of Green Buildings: From the Humanistic Needs to Social Acceptance. Renew. Sustain. Energy Rev. 2015, 51, 1594-1609. [CrossRef] 